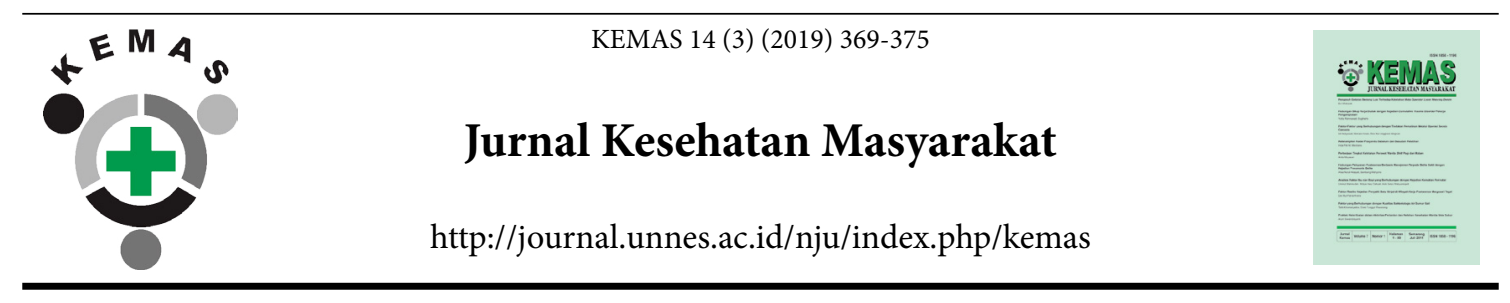

\title{
Why do I Follow the Program KB?
}

\author{
Arman Rifat Lette $\mathrm{e}^{1 凶}$ \\ ${ }^{1}$ Sekolah Tinggi Ilmu Kesehatan Citra Husada Mandiri Kupang, Indonesia
}

\begin{tabular}{l} 
Article Info \\
\hline Article History: \\
Submitted July 2018 \\
Accepted October 2018 \\
Published March 2019 \\
\hline Keywords: \\
Mother, Family \\
Planning Program, \\
Family Planning Acceptor \\
\hline DOI \\
https://doi.org/10.15294/ \\
kemas.v14i3.15247
\end{tabular}

\begin{abstract}
The behavior of mothers who want to become KB acceptor is interesting to be known and studied, considering the many negative views or perception about family planning such as: $\mathrm{KB}$ can disturb fertility, contrary to family planning, KB can disrupt health, the view that many children can bring a lot of fortune and etc. This study aims to Explores in depth the factors that pushed the mother into KB acceptor at clinic image of Pratama Citra Husada Kupang. Qualitative research with exploratory design and phenomenology approach. The main informants were mothers who became KB acceptor and supporting informants were the clinic head, BKKBN representative of NTT province and field officer of KB. Data collection is done by: 1. Observation; 2. In-depth interview. Factors that encourage mothers to accept family planning acceptors are: Do not bother to take care of children, Fear when pregnant again with close distance, Mother is in a state of urgency, Consider the child's education forward, Child's health is assured and affection to the child can be maximal, Experiencing Trauma in childbirth, To be more successful in the future, consider economic factors and for maternal and child health. Family Planning Program is beneficial for mothers, both physically and psychologically. Mothers who are not yet acceptor of KB need to consider joining family planning program because the benefits of family planning have been very proven in society.
\end{abstract}

\section{Introduction}

Hight population growth can be huge problem, particularly in developed and poor country. Robert Malthus, an economicdemographyc expert has reminded that population grows exponentially $(1,2,4,6,8,16$, etc) while economic and welfare grow sequencially $(1,2,3,4,5$, etc). Uncontrolled population can risk people, nation and country development and welfare. Population problem pressure increase causing many countries (governments) face a difficulty to provide basic requirements for their people like food, clothes, houses and jobs (Darahim, 2010).

Similar condition is taken place in Indonesia. Along with high teenage pregnancy caused by premarital sex behavior. One of the trigger is easy access to porn information and exposure (Suwarni \& Selviana, 2015; Gamelia \& Kurniawan, 2017). This lead to high risk pregnancy which also become largest problem and requires special concern (Kurniawan et al, 2017). Indonesia is a country with fourth largest population in the world. Indonesia is predicted to gain "demographic bonus" which is obtained by a country as a result of the large productive population proportion (age range 15-64 years old) in the population evolution, estimated will take time in year 2020-2030. In order to prepare this condition, then the government need to anticipate potential problems, like by Family Plan program (Kementerian Kesehatan

\footnotetext{
Correspondence Address:

Sekolah Tinggi Ilmu Kesehatan Citra Husada Mandiri Kupang, Indonesia.

Email : lette.arman@gmail.com
} 
Republik Indonesia, 2015).

One of strategic decision taken by Indonesia government to suppress population growth acceleration is national Family Plan program (KB). Among the objective of $\mathrm{KB}$ program is pregnancy arrangement by contraception method to prevent pregnancy and family plan. Economic growth acceleration to develop people welfare is obtained through population growth acceleration control program. KB program implemented and coordinated by the government, make it's status as national program (Darahim, 2010). Family plan is the implementation of fertilization arrangement methods to assist someone or a family to achieve certain objective. The objective meant is an intented pregnancy arrangement that does not contradictory to the law or regulation as well as Pancasila moral value and for the family welfare.

Among the objective of birth control are : so that the government can well fulfill the people life requirement, balance population distribution among the regions and decreased mother and child mortality rate. At the end, Indonesia will be able to join modern country group viewed from the aspect of people health and welfare. Thus each problem solving should be done through strategic policy so that the problem can be solved whether by the government or together with the people. $\mathrm{KB}$ program in Indonesia is conducted as people condition which is developing, religious and complex. Furthermore, $90 \%$ of the population are moslem. In their perception, based on conservative view, birth arrangement is not allowed in Islam (haram). Thus, the implementation of $\mathrm{KB}$ program in Indonesia has been doing gradually and adjusted with level of understanding and perception of most of the people has not had knowledge and access to modern technology (Darahim, 2010).

To achieve the objective, KB service should be supported by community member as $\mathrm{KB}$ movement agent and as $\mathrm{KB}$ active participant or $\mathrm{KB}$ acceptor. $\mathrm{KB}$ acceptor is community member following $\mathrm{KB}$ movement by uses contraception. $\mathrm{KB}$ acceptor according to the targed can be cathegorized in three phase which are postpone or prevent the pregnancy, sparsial pregnancy and stop or end pregnancy or fertility. $\mathrm{KB}$ acceptor is advised more to Fertile Age Pair (Pasangan Usia Subur/PUS) by contraception. Since in these ages, pair has more opportunity to gain descendant and can increase birth rate. $\mathrm{KB}$ acceptor followed by PUS can be cathegorized in three group : 1) new KB acceptor or participant, which is PUS who uses contraception for the first time after a pregnancy that resulting of misbirth or birthing. 2) Old $\mathrm{KB}$ acceptor or participant which is still using contraception without interupting by pregnancy. 3) $\mathrm{KB}$ method shifter which is $\mathrm{KB}$ participant who shifts from one contraception method to another (Kementerian Kesehatan Republik Indonesia 2015).

There are many factors causing a mother refuses to join KB program. One of the factors is lack of knowledge and understanding of $\mathrm{KB}$ program and how to get KB program service. Beside the side effect of the method can be a reason considered by the mother to be participant. It has been proven that the usage of implant and injection contraception contribute a chance to gain additional body weight (Sriwahyuni \& Wahyuni, 2012; Nault et al, 2013)

Perception and attitude of the mother also affect the usage of $\mathrm{KB}$ method. The contraception matter in the community is caused by negative perception to it. Various rumors spread among the people oftenly fear them to use contraception. The perceptions make people afraid to adopt the methods offered by KB program (Maryam, 2014).

There is relation between mother perception to Family Planning program by contraception usage. The choice of contraception usage by the respondents is relied to what the respondent know therefore affect the respondent and behavior in contraception usage. This can be caused by the respondent thinks and chooses to use contraception that quick, practical and affordable (Maryam, 2014).

Unwanted pregnancy not only experienced by premarital couple, but also by husband and wife. Unwanted pregnancy become a significant issue since it brings negative effect not only to the mother but also to the child to be borned. Therfore, it requires a family plan service to prevent the unwanted pregnancy (Vigoureux et al, 2017). Mothers 
behavior willing to be $\mathrm{KB}$ acceptor is interested to be known and studied, consider the large negative views or perceptions about $\mathrm{KB}$, such as : KB can disturb mother fertility, contradictive to the religion, it can affect health, a thought that many children bring welfare, etc. Among the perception of poor/bacward community is each family happy to have many children since the will come along with usefulness (benefit) as their norm "many children bring welfare".

The Citra Pratama Husada Clinic in Kupang is a health service centre for : 1) general polyclinic for general healt examination and medication, 2) Mother and child clinic for mother and child health examination particularly pregnant mother, 3) UKGS polyclinic 4) Home care service 5) Ambulance service and 6) $\mathrm{KB}$ polyclinic for $\mathrm{KB}$ service to mothers or PUS. Based on initial observation, can be seen that during the KB service day, a lot of women came to get KB service.

Based on this observation, the researcher is interested to do a research regarding mother became KB acceptor behavior at Citra Pratama Husada Clinic in Kupang. The objective of the research is to deeply find out the factors supporting the mothers to be $\mathrm{KB}$ acceptor at Citra Pratama Husada Clinic in Kupang.

Method

The research method is qualitative research with exploration design and phenomenologic approach. The main informant is mother becoming $\mathrm{KB}$ acceptor and supporting informant is the clinic head, NTT province BKKBN (National Family Plan Coordination Board) representative and $\mathrm{KB}$ field attendant. Data is collected by : 1) Observation; 2) Indepth Interview. The informants are selected by purposive sampling technique with convenience sampling strategy. First indepth interview is conducted to core informants, which are $\mathrm{KB}$ acceptor mothers. It was taken place in Citra Pratama Husada Clinic examination room. Then interview is conducted to clinic attendant, NTT province $\mathrm{BKKBN}$ representative and $\mathrm{KB}$ field attendant. To gain core informant, researcher waited at the clinic and requested the mothers avilability after being examinated or KB service. The interview was conducted after the informant signed the informed consent. The researcher also doing an observation related with KB method service.

The data analysis is conducted through qualitative analysis, involving steps as follow : 1) Transcript making; 2) Data coding with open code program; 3) Information cathegorization, which mean grouping similar information from coding result into a matrix and each cathegory is analyzed based on research theme (final cathegory); 4) Intrepretation of the information, data presentation and conclusion in form of research report. Variables observed are attitude, significant others, information source and supporting factors related with mother behavior to be KB acceptor.

\section{Result and Discussion}

The subjects in this researach are 14 persons consisting of $11 \mathrm{~KB}$ acceptor mothers and 3 supporting informants, who are clinic attendant, BKKBN representative and KB field attendant. Number of female informants are 12 persons and male 2 persons.

Table 1. Informant Characteristic

\begin{tabular}{ll}
\hline Informant characteristic & Number \\
\hline Elementary: & \\
SD & 3 persons \\
SMP & 5 persons \\
SMA & 5 persons \\
DIV/S1 & 1 person \\
S2 & 2 persons \\
Age : & 7 persons \\
<25 years & 5 persons \\
$25-40$ years & 2 persons \\
W0years & 6 persons \\
PNS & 5 persons \\
Swasta & 1 person \\
Ibu rumah tangga &
\end{tabular}

Source : Primary Data, 2017

The informants are taken based on the criteria earlier determined. Beside interviewing the mother that will become $\mathrm{KB}$ acceptor as main informant, researcher also interview the clinic attendant, NTT province BKKBN representative and $\mathrm{KB}$ field attendant as supporting informants. Beside the interview, researcher also conduct an observation at Citra Pratama Husada Clinic in Kupang.

Informant age is between 24-65 years 
old. Based on education level, mostly is senior high and graduate, as many as 5 persons. The informants particularly mothers becoming $\mathrm{KB}$ acceptor said that supporting factor to join the $\mathrm{KB}$ program is because they don't want to be hassle in taking care more children since both husband and wife are working.

\section{"Because my first child has been 15 years old. So it's confusing. We can't be hussle again. My husband and I both work so nobody home" \\ $K B$ acceptor mother (DK, 34 years old)}

From the result also can be seen the reason of mother to be $\mathrm{KB}$ acceptor is she is worried to be pregnant again in close period.

\footnotetext{
"Well it's because my first child still 5 months old, meanwhile I pregnant again.. So I decided after 40 days of giving birth, I joined KB program. I am worried to be pregnant again".

$K B$ acceptor mother (DS, 34 years old)
}

There was also informant said the reason to joint $\mathrm{KB}$ program is already has many children with close range of birth time and the mother feels hussle to take care her children, thus she accepted to join KB program.

"I want to arrange birth distance between my children. I have had six children by the way, so there is a university student asking me to have $K B$ implant. So I come. I have six children with close birth distance. It's so hassle. I thought to use KB implant". $K B$ acceptor mother (AT, 29 years old)

Another mother become KB acceptor also with the reason to arrange birth distance properly so she does not have problem in children education.

"So when I was young, I saw a mother having such an early age child yet she had been pregnant again. So I thought when I married, I would not be like that. So I arrange my birth distance. Because when the birth distance is not arranged, when the children come in time to go to school, the parents will be hassle. When my child reach the age of kindergarten and just about to enter elementary, then I intent to pregnant". $K B$ acceptor mother ( $Y K, 41$ years old)

One mother becoming KB acceptor said the reason is to arrange birth distance so she can take good care of her children and make sure the children health (do not have under or poor nutrition)

"I want to arrange birth distance so that my children do not have poor nutrition and such thing. Another reason is to have maximum attention and love of the children. Those are the reasons I join this KB program.".

$K B$ acceptor mother (SM, 41 years old)

Mother becoming $\mathrm{KB}$ acceptor due to traumatic experience during giving birth, where she was on critical condition in second birth giving. Therefore, she planned not to be pregnant and giving birth again.

"So I do not have children anymore. No.. Not that I want to arrange the birth distance. I don't want to have children anymore. If I want to arrange birth distance, I should have had child again. But I don't want more children. Well not that I don't want the children but because I had traumatic expreience when I delivered the baby, so I don't want it to happen again. Two children are enough. I was on critical condition when I delivered my last child. So two are enough."

KB acceptor mother (LM, 44 years old)

Informant also said the reason to join $\mathrm{KB}$ program is to be more success in the future and avoid inconvenience. She saw that having many children makes the mother inconvenience.

"So we can be success in the future, do not have many children so we won't be inconvenience. Some people said many children, many fortune. But nowadays is just the same. Better join the KB program than have many children. So in the future, we will be happier, more success. Event for going out it can be difficult due to many children". 
KB acceptor mother (HS, 26 years old)

Informant also said the reason that the mother willing to joint $\mathrm{KB}$ program is due to income factor or family economic condision consideration.

\begin{abstract}
"People said many children many fortune, yet if we can give sufficient attention, then what a pity... So better we arrange as our income, that's it.. not that we ask to have many children. But many children with low income? That will not be good. Having children, but not take a good care of is not good.. just the same..”.

$K B$ acceptor mother ( $M N, 31$ years old)
\end{abstract}

BKKBN representative and $\mathrm{KB}$ field attendant also confirm that for the mother and children health should be the reason or main supporting factor so that the mothers willing to be KB acceptor.

\begin{abstract}
"so for the mother actually I strongly advise. family plan is really.. really useful for mother and child health. Family plan objective is to avoid the mother to be too.... well I think from the perspective of health should be like that. So that the mother health, well being, beautiful, have more time to work to help the husband to increase family income to have a happy and welfare family. That's what we campaigning... so always for the health of mother and child."

$B K K B N$ representative ( $M K, 53$ years old)
\end{abstract}

From the result can be seen that the factors supporting a mother to joint $\mathrm{KB}$ program are does not want to be hussle in taking care the children and considering that both husband and wife work. The mother become $\mathrm{KB}$ acceptor is also due to joint decision between husband and wife. Joint decision more supporting the mother to be KB acceptor (Uddin et al, 2016). This also support by the clinic attendant stating that factor supporting the mother to be $\mathrm{KB}$ acceptor is due to the mother has a job and feel difficult to spare time to take care the children. Since she feel hussle in taking care the children and in addition should be focus to her job, then some mothers choose to be KB acceptor. It also related with previous pregnancy. The experience on last pregnancy will be related with the decision to joint KB program. A pregnant mother feeling hussle/depress in the pregnant period and in taking care the children will decide to join $\mathrm{KB}$ program (Strøm-Roum et al, 2016).

From the result also known that factor supporting mother to be $\mathrm{KB}$ acceptor is a worriness to be pregnant in short distance period. The experience to giving birth in short distance time causes the mother worry so that she decides to be $\mathrm{KB}$ acceptor. Objectively view, it can be said that worriness beside to have negative aspects, which intriques and causing the tense feelings and body symthomps, also contains positive aspect. Worriness is one of main power pushing and moving. Reaction is emerged inside the individual, then move the individual to preserve the self from outside impulse or threat, keep self away from something threat, harm the self and other hazard. Therefore, it is clear that worriness has positive and negative value. Positive, since it protects the individual from hazard circumstances. In this case, when a mother consider if pregnant and giving birth within short distance time is a hazard condition and harm her self, then the mother will have positive worriness. And finally it supports the mother to be $\mathrm{KB}$ acceptor.

Informant also mention that the reason or factor supporting to follow KB program is due to already have many children with close distance birth time. It can be said the mother has been in recessive condition due to the hassles in taking care of the children. There is an informant ages 29 years yet has had 6 children with short distance periods. Thus altough from the knowledge she has not had sufficiently yet the condition pushed her to join the KB program.

The research of Strøm-Roum et al (2016) showed $60 \%$ of women in Norwegia reported they do not use contraception when found out pregnant and giving birth. This indicates the usage of contraception still be an importan strategy to prevent pregnancy on woman to have more welfare family. Therefore, counseling method is very important to emerge 
the intention of a mother to follow KB program (Cohen et al, 2017; Faisal-Cury et al, 2013). The contraception usage also related with young age, when more young mother (age 20-35 years old) following KB program (Strøm-Roum et al, 2016).

Mother becoming KB acceptor also said the reason is to manage the birth distance properly so she does not meet difficulty in sending the children to school. The mother concern about the children future, where they can get well education and good future. This also related with family welfare in the future. Considering the risk factor and protection have effect to consistant contraception usage among the mother that still on college. The mother also consider protection obtained from KB program (family welfare, children education, etc) thus she consistantly follow the program (Morrison et al, 2016).

The informan also said the reason to follow $\mathrm{KB}$ program is due to traumatic event in giving birth when the mother was in critical condition on second birth giving. This make the mother plans not to pregnant and giving birth anymore. Trauma is a physical as well as psychological reaction that has bad stress purpose due to an event, incident, or experience which is spontanious/sudden, causing the individual to be surprised, shock or feared, unconcious, etc that not easily forgotten. Due to the traumatic event during the second birth giving, the mother follows the $\mathrm{KB}$ program.

Research result also mention the reason of following KB program is to be more success in the future and avoid difficulty. There is a mother ages 26 years old and already has 4 children with quite close birth distance. On the other side, the mother still on college and willing to have better job, but due to she has to take care the children then her education is left behind. The mother willing to follow $\mathrm{KB}$ program to reach better future and success. She consider has many children will be hussle.

Another informant mentioned the reason to follow KB program is family income or economy. With low income she feel difficult to fulfill family requirement with many children. Yet nowadays fertile age women with low socio economical condition still has a stigm that more children means more person will take care the parent in the old time (Sunarsih et al, 2015).

Economic level will affect someone requirement, the higher then it will be easier to fulfill the requirement. Other than that, economic level also affect family requirement fulfillness. There is informant considering economical factor due to low income. When the income is low yet number of children is high then family life will be in problem, due to inability to pay the children requirement.

$\mathrm{BKKBN}$ representative and $\mathrm{KB}$ field attendant also confirm that for the mother and children health should be main supporting factor for the mothers to be $\mathrm{KB}$ acceptor. $\mathrm{KB}$ program prevent the mother from " 4 too". Too young, too old, too many and too close. Through the plan, family can determine size of the family, precise time to have children and used contraception method. The decision to plan a family is related with many consideration like physical and psychological readiness, family financial condition and last but not least is mother and children health (Morrison et al, 2016). Beside the purpose of decreasing birth rate, the fellowship of $\mathrm{KB}$ program also to increase the people welfare, particularly the mother and children. Community welfare improvement, particularly the improvement of health will decrease mortality rate, evenmore the infant and the children.

Those considerations then should determine family decision to immediately or postpone the pregnancy. For a family, the decision to postpone a pregnancy can be done with proper contraception method, including after a birth giving process. Basicly contraception can be used by a couple willing to control fertility or postpone the pregnancy or for them who for various reasons do not want any more children. The usage of contraception should be supported specially by closest persons (husband, family and parent) (Usinger et al, 2016; Nilawati \& Hirawati, 2014). The necessity to consider ideal pregnancy distance also help to prevent premature birth and/or low weight birth. By arrange number and distance of birth then mother will gain benefit like : health improvement caused by repeated pregnancy in short time and improvement of social and psychological health as result of sufficient time 
to take care the children, rest and enjoy spare time to do other activity.

\section{Conclussion}

$\mathrm{KB}$ program is beneficial to the mother physically and psychologically. It help the mother to plan and reach better family future. One of important thing is it help the mother to prevent fear and worriness in taking care many children. The mothers that have not been a KB acceptor should consider to follow it due to proven benefit in the community.

\section{Acknowledgement}

The writer would like to acknowledge the STIKes CHMK institute for funding this research. Also to all the mothers, clinic attendants, BKKBN representative and KB field attendant willing to be informant to complete this research.

\section{References}

Cohen, R., Sheeder, J., Kane, M., Teal, S. B., 2017. Factors Associated With Contraceptive Method Choice and Initiation in Adolescents and Young Women. Journal of Adolescent Health, 61(4), pp.454-460.

Darahim., 2010. Kependudukan dan peran pendidikan kependudukan dalam mendukung program KB Nasional, Jakarta: BKKBN.

Faisal-Cury, A., Menezes, P.R., \& Huang, H., 2013. The Relationship between Perinatal Psychiatric Disorders and Contraception Use Among Postpartum Women. Contraception, 88, pp.498 - 502.

Gamelia, E., \& Kurniawan, A., 2017. Determinant Of Teenage Pregnancies. Jurnal Kesehatan Masyarakat (KEMAS), 13(2), pp.270-276.

Kementerian Kesehatan Republik Indonesia., 2015. Buku Ajar Kesehatan Ibu dan Anak, Jakarta: Pusat Pendidikan dan Pelatihan Tenaga Kesehatan.

Kurniawan, A., Sistiarani, C., \& Hariyadi, B., 2017. Early Detection Of High Risk Pregnancy. Jurnal Kesehatan Masyarakat (KEMAS), 13(2), pp.96-103.

Maryam, S., 2014. Analisis Persepsi Ibu Tentang Program Keluarga Berencana (KB) Dengan Penggunaan Kontrasepsi Di Desa Sumberdadi, Kecamatan Sumbergempol Kabupaten Tulungagung Tahun 2014. Jurnal Universitas Tulungagung Bonorowo, 1(2).

Morrison, L.F., Sieving, R.E., Pettingell, S.L., Hellerstedt, W.L., McMorris, B.J., \& Bearinger, L.H., 2016. Protective Factors, Risk Indicators, and Contraceptive Consistency Among College Women. Journal of Obstetric, Gynecologic, and Neonatal Nursing : JOGNN, 45(2), pp.155-165.

Nault, A.M., Peipert, J.F., Zhao, Q., Madden, T., \& Secura, G.M., 2013. Validity of Perceived Weight Gain in Women Using Long-Acting Reversible Contraception and Depot Medroxyprogesterone Acetate. American Journal of Obstetrics \& Gynecology, 208(48), pp.1-8.

Nilawati, S., \& Hirawati, H., 2014. Hubungan Dukungan Suami dengan Kepatuhan Akseptor KB Suntik Progestin Melakukan Suntik Ulang di BPM Ny. Supiyah, Amd. Keb Desa Muntung Kecamatan Candiroto Kabupaten Temanggung. Jurnal Keperawatan Maternitas, 2(2), pp.98-105.

Sriwahyuni, E., \& Wahyuni, C., 2012. Hubungan antara Jenis dan Lama Pemakaian Alat Kontrasepsi Hormonal dengan Peningkatan Berat Badan Akseptor. The Indonesian Journal of Public Health, 8(3), pp.112-116.

Strøm-Roum, E.M., Lid, J., \& Eskild, A., 2016. Use of Contraception Among Women Who Request First Trimester Pregnancy Termination in Norway. Contraception, 94, pp.181-186.

Sunarsih, E.N., \& Damayati, R., 2015. Faktor-faktor yang Berhubungan dengan Penggunaan Alat Kontrasepsi pada Wanita Usia Subur (WUS) di Kelurahan Campang Raya Bandar Lampung Tahun 2014. Jurnal kebidanan, 1(3), pp.110-115.

Suwarni, L., \& Selviana, S., 2015. Inisiasi Seks Pranikah Remaja dan Faktor yang Mempengaruhi. Jurnal Kesehatan Masyarakat (KEMAS), 10(2), pp.169-177.

Uddin, J., Pulok, M.H., \& Sabah, M.N.U., 2016. Correlates of Unmet Need for Contraception in Bangladesh: Does Couples' Concordance in Household Decision Making Matter? Contraception, 94, pp.18-26.

Usinger, K.M., Gola, S.B., Weis, M., \& Smaldone, A., 2016. Intrauterine Contraception Continuation in Adolescents and Young Women: A Systematic Review. Journal of Pediatric and Adolescent Gynecology, 29(6), pp.1-9.

Vigoureux, S., Bajos, N., \& Ringa, V., 2017. Effect of Parent-Daughter Communication about Sex on the Use of Less Effective Contraception among Women from Ages 15-24 Years in France. Journal of Pediatric and Adolescent Gynecology, 31(1), pp.33-39 